\title{
Influence of gibberellic acid on vegetative, floral and corms yield of gladiolus cultivars under the agro-climatic condition of Peshawar-Pakistan
}

\author{
Abdur Rahman ${ }^{1}$, Ghulam Nabi ${ }^{1}$, Waqas Khan ${ }^{1}$, Muhammad Noman \\ Khan $^{1}$, Majid Hissam ${ }^{1}$, Muhammad Ilyas ${ }^{1 *}$, Babar Ali $^{1}$ and Yasir Ali ${ }^{2}$ \\ 1. Department of Horticulture, The University of Agriculture Peshawar-Pakistan \\ 2. Department of Horticulture, Pir Mehr Ali Shah Arid Agriculture University Rawalpindi-Pakistan \\ *Corresponding author's email: muhammadalyas12322@gmail.com
}

Citation

Abdur Rahman, Ghulam Nabi, Waqas Khan, Muhammad Noman Khan, Majid Hissam, Muhammad Ilyas, Babar Ali and Yasir Ali. Influence of gibberellic acid on vegetative, floral and corms yield of gladiolus cultivars under the agro-climatic condition of Peshawar-Pakistan. Pure and Applied Biology. Vol. 8, Issue 1, pp559-571.

http://dx.doi.org/10.19045/bspab.2018.700217

Received: 03/10/2018 Revised: 21/12/2018

Accepted: $24 / 12 / 2018$

Online First: 29/12/2018

\section{Abstract}

Gladiolus is an important cut flower commercialized in Pakistan, and the use of gibberellic acid $\left(\mathrm{GA}_{3}\right)$ to cultivate it in the Peshawar valley may promote the production of high quality flower spikes. Therefore, an experiment "Influence of Gibberellic acid on vegetative, floral and corm yield of gladiolus cultivars" was conducted under the climatic condition of Peshawar, during 2016. The experiment was laid out in two factors Randomized Complete Block Design there were five treatments replicated three times. Factor "A" was the gibberellic acid $\left(\mathrm{GA}_{3}\right)$ concentrations i.e. 0, 50, 100, 150, $200 \mathrm{mgL}^{-1}$ Factor "B" was the two cultivars of gladiolus i.e., White Prosperity and Red Advance. It revealed from the results that most of the parameters were significantly influenced by gibberellic acid at $200 \mathrm{mgL}^{-1}$. The maximum sprouting percentage (96.25), number of leaves plant ${ }^{-1}$ (10.6), number of floret spike ${ }^{-1}$ (14.4), number of shoots plant $^{-1}$ (3.17), number of daughter corm plant ${ }^{-1}$ (3.54) and survival percentage (88.50), less days to corm sprouting (17.9), number of days to spike emergence (48.83), days to floret opening (72.73) were recorded in plants treated with $200 \mathrm{mgL}^{-1}$ of gibberellic acid $\left(\mathrm{GA}_{3}\right)$ concentration. Whereas, the maximum plant height $(75.62 \mathrm{~cm})$, length of spike plant ${ }^{-1}(57.15 \mathrm{~cm})$, corm diameter $(3.37 \mathrm{~cm})$ corm weight $(14.90$ g) were recorded in plants treated with $150 \mathrm{mgL}^{-1}$ Gibberellic acid. Red advance produced more number

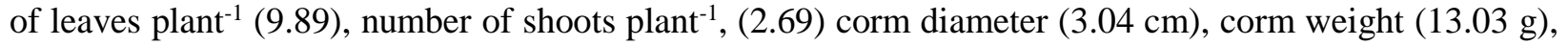
survival percentage (70.9), less number of days to spike emergence (53.8) and days to floret opening (74.5). It can be concluded from the present findings that the treatment of corms with $200 \mathrm{mgL}^{-}$ ${ }^{1}$ gibberellic acid can improve the growth and yield of Red Advance cultivar of gladiolus under the agroclimatic conditions of Peshawar valley.

Keywords: Corm yield; Flower production; Gibberellic acid; Gladiolus cultivars; Vegetative growth

\section{Introduction}

Gladiolus (Gladiolus grandiflorus), is an ornamental flowering plant. It's another name is "Sword Lily" and its origin is South Africa. It is a monocot plant and belongs to family Irideaceae. Upto now its one hundred 
and fifty species are known [1]. Gladiolus has herbaceous stem and narrowly linear leaves, sheathing at the base and side are flattened. Its flowers are bisexual [2].

Gladiolus bears unparallel elegance, aesthetic an economic value for its beauty. It is frequently used in landscape, bedding and gardens is an excellent cut flower. These are also widely used in bouquets, in flower arrangements, artistic garland, etc. The gladiolus has captured a major share in the local and world floriculture markets, for its attractiveness and assortment of cultivar of colors [3].

The high ranker countriesof gladiolus production are America, Italy, Australia, Poland, Holland, India, Iran, Singapore and Malaysia. However gladiolus cut flower spikes quality and its mass production is still trouble in numerous countries. Due to low production of cormels and corms, its commercial cultivation is still limited [4].

A lot of factors i.e. corm size, sowing depth, planting time, management of fertilizer and use of growing hormones like $\mathrm{GA}_{3}$, Indole Acetic acid (IAA) etc., can influence the quality and production of gladiolus flowers and its corm and cormel size are increases. Bulbous crops are greatly influenced by the bulbs or corms size. Gladiolus corm is the propagule and food-storing underground stem. The corm size highly influences thedevelopment and vegetative growth, ultimately thecorms production, flowers and spike [5].

Gibberellic acid increases height of theplants, number of leaves, number of flowers, induce early flowering and also increase the yield of gladiolus at different concentrations [6]. Being a potential cut flower gladiolus grown worldwide due to its huge demand. The gladiolus spikes and florets have good looking stunning color, Long vase life and different sizes [7].

The objectives of this study were to investigate the response of two gladiolus cultivars to gibberellic acid treatments and to determine the effects of these treatment on growth and corms yield of two gladiolus cultivars.

Considering the above facts, the present experiment was designed, to study "The Influence of Gibberellic acid on vegetative floral and corms yield of gladiolus Cultivars", with the following objectives. To explore the suitable cultivar for growth and production of gladiolus. To find out the optimum concentration of Gibberellic acid for growth, flower and corms production of gladiolus. To determine the interactive effect of Gibberellic acid concentration and gladiolus cultivars on the growth and production of gladiolus.

\section{Materials and methods}

The experiment entitled "Influence of gibberellic acid on vegetative, floral and corms yield of gladiolus cultivars" was conducted during the year 2016 at Horticulture field in Agriculture Research Institute Tarnab, Peshawar.

The experiment was laid out in Randomized Complete Block Design with two factors.During the experiment the corms of Gladiolus cultivars (White Prosperity and Red Advance) were treated with five different concentration of Gibberellic acid $\left(0,50,100,150\right.$ and $\left.200 \mathrm{mgL}^{-1}\right)$ and was replicated three times. A total of 24 corms were used per treatment. As Gibberellic acid is not easily dissolved in water for this purpose, Ethanol was added for dissolving Gibberellic acid into water. Corm soaking was done in Gibberellic acid solutions for about 24 hours before corm sowing.

\section{Parameters studied}

Data were recorded on the following parameters:

\section{Days to corms sprouting}

Number of days for corms sprouting was counted from the date of corms sowing to the date of corms sprouting and the average was calculated. 


\section{Corms sprouting percentage}

The sprouted corms were counted from the first sprouting to the last sprouting and the percentage was calculated by the following formula.

Sprouting

percentage

$=\frac{\text { Number of corms sprouted }}{\text { Total number of corms planted }} \times 100$

Number of leaves plant $\mathbf{t}^{-1}$

Number of leaves plant ${ }^{-1}$ was recorded by counting the number of leaves in each treatment in every replication and then average was calculated.

\section{Days to spike emergence}

Number of days for Spike emergence was counted from the date of corm sowing to the first spike emergence and average was calculated.

\section{Plant height (cm)}

Plant height was measured with the help of measuring tap in each treatment in every replication from the ground level to top of flowering spike then average was calculated.

Number of floret spike ${ }^{-1}$

Number of floret spike ${ }^{-1}$ was counted in of each treatment in every replication and then average was calculated.

\section{Number of shoots plant ${ }^{-1}$}

The average number of shoots plant ${ }^{-1}$ was recorded by counting the number of shoots in each treatment in every replication and then average was calculated.

\section{Length of spike $(\mathrm{cm})$}

The spike length was measured from the base of the flower spike with the help of measuring tap from each treatment in every replication and then average was calculated.

\section{Days to flower opening}

Data regarding days to flowering emergence was recorded from the date ofcorms planted to flower emergence and then average was calculated.

\section{Number of daughter corms plant ${ }^{-1}$}

Data pertaining number of daughter corms was counted in each treatment in every replication and their mean was computed.

\section{Diameter of daughter corms (cm)}

Diameter of corms was recorded with the help of Vernier caliper for all treatments in every replication and then average was calculated.

\section{Corms weight (g)}

The weight of the harvested daughter corms was recorded in each treatment in every replication by using electronic balance and average was calculated.

\section{Survival percentage}

Number of survived plants were recorded and the averages were then calculated with the following formula.

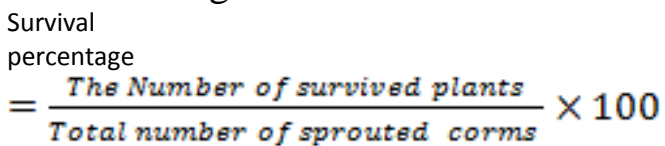

\section{Statistical procedure}

The data was collected on various parameters and was applied analysis of variance (ANOVA) to view the difference between treatments as well as interaction. In case when the difference was significant, it was assess for difference through least significant difference (LSD) test. Statistical computer software "Statistix 8.1" was applied for computing both ANOVA and LSD at $5 \%$ level of probability [8].

\section{Results and discussion}

The results pertaining to different growth and flowering parameters are described as under.

\section{Days to corms sprouting}

Data regarding days to corms sprouting of gladiolus are mentioned in (Table 1) which showed that the various Gibberellic acid concentration had significant effect on days to corm sprouting of gladiolus. While cultivars and their interaction showed nonsignificant results.

The mean values pertainingthat less number (17.9) of days were observed in plants with the application of $200 \mathrm{mgL}^{-1}$ gibberellic acid $\left(\mathrm{GA}_{3}\right)$ treatment, followed by (18.8) days with the application of $150 \mathrm{mgL}^{-1}$ gibberellic acid $\left(\mathrm{GA}_{3}\right)$ treatments, while more number 
(22.8) of dayswere taken by plants in control treatment.

The highest days to corm sprouting was observed in control treatment, while minimum number days to corms sprouting observed in plants treated with $200 \mathrm{mgL}^{-}$
${ }^{1}$ gibberellic acid $\left(\mathrm{GA}_{3}\right)$.It might be due to the high nutrients preserved and gibberellic acid which can enhanced the cell expansion and promotes synthesis of DNA in cells. These findings are in line with $[9,10]$.

Table 1. Influence of gibberellic acid concentrations and cultivars on the days to corm sprouting of gladiolus

\begin{tabular}{|c|c|c|c|c|c|c|}
\hline \multirow{2}{*}{ Cultivars } & \multicolumn{5}{|c|}{ Gibberellic acid concentrations $\left(\mathrm{mgL}^{-1}\right)$} & \multirow[t]{2}{*}{ Mean } \\
\hline & (0 & 50 & 100 & 150 & 200 & \\
\hline White Prosperity & 22.7 & 21.7 & 20.0 & 18.4 & 17.9 & 20.18 \\
\hline Red Advance & 22.8 & 21.4 & 20.3 & 19.3 & 18.0 & 20.39 \\
\hline Mean & 22.8a & 21.5ab & 20.1bc & 18.8cd & 17.9d & \\
\hline
\end{tabular}

\section{Corms sprouting percentage}

Data pertaining days to corms sprouting percentage of gladiolus are shown in (Table 2) which revealed that gibberellic acid concentrations having significant effect on sprouting percentage of gladiolus. While cultivars and interaction showed nonsignificant results. The mean values of Table-2, presented that more sprouting percentage (96.3) was recorded in plants treated with $200 \mathrm{mgL}^{-1}$ gibberellic acid, followed by (91.71) with $150 \mathrm{mgL}^{-}$ ${ }^{1}$ gibberellic acid treatment, while less sprouting (71.1) percentage were noted in control treatment.

The balance between growth promoters hormones and growth retardant hormones can play an important role in plant growth and development. As Abscisic acid is dominant and hence responsible for the dormancy in gladiolus corms. The freshly harvested corms of gladiolus having dormancy for the period of three months. Reduction in the level of ABA is the major factor causing endogenous hormonal balance, which promotes the sprouting percentage in gladiolus corms. Gladiolus corms treated with $150 \mathrm{mgL}^{-1}$ and $200 \mathrm{mgL}^{-}$ ${ }^{1}$ gibberellic acid concentrations resulted in highest sprouting percentage 91.7 , and 96.3 as mentioned in table-4.2. Which shows that, $150 \mathrm{mgL}^{-1}$ and $200 \mathrm{mgL}^{-1}$ gibberellic acid application was actively involved in the breaking of reserved food material with the help of hydrolytic enzymes present in $\mathrm{GA}_{3}$ which might have result in highest sprouting percentage

[11].

Table 2. Influence of gibberellic acid concentrations and cultivars on the corm sprouting percentage of gladiolus

\begin{tabular}{|c|c|c|c|c|c|c|}
\hline \multirow{2}{*}{ Cultivars } & \multicolumn{5}{|c|}{ Gibberellic acid concentrations $\left(\mathrm{mgL}^{-1}\right)$} & \multirow[t]{2}{*}{ Mean } \\
\hline & 0 & 50 & 100 & 150 & 200 & \\
\hline White Prosperity & 71.3 & 79.3 & 78.4 & 95.8 & 96.7 & 84.3 \\
\hline Red Advance & 71.3 & 75.0 & 92.5 & 92.5 & 95.8 & 84.3 \\
\hline Mean & 71.8d & $77.2 \mathrm{~cd}$ & $85.4 \mathrm{bc}$ & 91.7ab & 96.3a & \\
\hline
\end{tabular}

\section{Number of leaves plant $\mathbf{t}^{-1}$}

Data related to number of leaves plant ${ }^{-1}$ of gladiolus is given in (Table 3 ) revealed that numbers of leaves plant $^{-1}$ was significantly affected by cultivars and Gibberellic acid concentrations, while the interaction 
between cultivars and gibberellic acid concentrations showed non-significant results. The mean value of different cultivars of gladiolus showed that more number (9.8) of leaves plant $^{-1}$ were produced by Red Advance and minimum number (8.4) of leaves plant ${ }^{-1}$ were noticed in White Prosperity. Data recorded for gibberellic acid treatment is mentioned in Table-3, which shows that maximum number (10.6) of leaves plant ${ }^{-1}$ were produced in plants treated with $200 \mathrm{mgL}^{-1}$ gibberellic acid, followed by (10.2) in plants that were treated with $150 \mathrm{mgL}^{-1}$ gibberellic acid while, the minimum numbers (7.6) of leaves plant $^{-1}$ were recorded in plants in control treatment.

There are different factors which can enhance the growth of gladiolus cultivars that can be the genetic makeup of cultivars or may be the favorable environmental conditions. Hence more number of leaves plant $^{-1}$ in Red Advance may be due to the genetic makeup or availability of suitable environmental conditions [12]. An increase in growth parameter i.e., number of leaves, with the application of $\mathrm{GA}_{3}$ mightbe the enhanced cell division accured in shoot tip with cell elongation and growth promotory action of gibberellic acid. These findings are in lined with $[13,14]$. Moreover increased in growth parameters may be due to the function of $\mathrm{GA}_{3}$ in plant tissues. Hence $\mathrm{GA}_{3}$ is known to be actively involved in various plant development process [15]. In various studies, gibberellin application exogenously found as a promoter of shoot elongation and vegetative growth [16-18].

Table 3. Influence of gibberellic acid concentration and cultivars on the number of leaves plant $^{-1}$ of gladiolus

\begin{tabular}{|c|c|c|c|c|c|c|}
\hline \multirow{2}{*}{ Cultivars } & \multicolumn{5}{|c|}{ Gibberellic acid concentrations $\left(\mathrm{mgL}^{-1}\right)$} & \multirow[t]{2}{*}{ Mean } \\
\hline & $\mathbf{0}$ & 50 & 100 & 150 & 200 & \\
\hline White Prosperity & 7.0 & 7.9 & 9.0 & 8.6 & 9.8 & $8.4 b$ \\
\hline Red Advance & 8.3 & 8.3 & 9.3 & 11.7 & 11.4 & $9.8 \mathrm{a}$ \\
\hline Mean & $7.6 \mathrm{~b}$ & 8.1b & 9.0ab & $10.2 \mathbf{a}$ & $10.6 \mathbf{a}$ & \\
\hline
\end{tabular}

\section{Days to spike emergence}

Data regarding for days to spike emergence of gladiolus is mentioned in (Table 4) which showed that cultivars and Gibberellic acid concentrations are highly significant and the interaction between cultivars and Gibberellic acid are non-significant on the number of days to spike emergence of gladiolus. Mean value of Table-4 indicated that less no. of days to emergence of spike (52.20) was noticed in Red Advance cultivar. While more no. of days to emergence of spike (60.50) was observed in White Prosperity cultivar.The mean value of different Gibberellic acid concentrations proved that less number of days to spike emergence (48.8) was noticed in plants with the application of $200 \mathrm{mgL}^{-1}$ gibberellic acid treatment, followed by (52.2) days in 150 $\mathrm{mgL}^{-1}$ gibberellic acid treatment, while more number (60.5) of dayswere taken by plants in control treatment.

Lessnumber of days to spike emergence in Red Advance cultivar might be due to the presence of more photosynthesis. As more number of leaves were noticed in Red Advance which may serve as plenty of photosynthates synthesis factories and decrease the time for spike emergence. Hence the presence of more photosynthates in Red Advance cultivar, assisted the plant to complete their life cycle before than those that had less no. of leaves. As a result earlier spike emergence was found in Red Advance cultivar [19]. Minimum days to spike emergence may be due to the stimulating 
effect of the gibberellic acid [20]. These findings are in contrast with [21] who used different gibberellic acid concentrations and found minimum days to spike emergence on $100 \mathrm{mgL}^{-1}$.

Table 4. Influence of gibberellic acid concentration and cultivars on the days to spike emergence of gladiolus

\begin{tabular}{|c|c|c|c|c|c|c|}
\hline \multirow{2}{*}{ Cultivars } & \multicolumn{5}{|c|}{ Gibberellic acid concentrations $\left(\mathrm{mgL}^{-1}\right)$} & \multirow[t]{2}{*}{ Mean } \\
\hline & $\overline{0}$ & 50 & 100 & 150 & 200 & \\
\hline White Prosperity & 61.0 & 57.7 & 55.3 & 53.4 & 49.3 & 53.3a \\
\hline Red Advance & 60.0 & 56.3 & 53.3 & 51.0 & 48.3 & $\mathbf{5 3 . 8 b}$ \\
\hline Mean & $60.5 a$ & $57.0 b$ & $54.3 \mathrm{c}$ & 52.2d & 48.8e & \\
\hline
\end{tabular}

\section{Plant height (cm)}

The mean value pertaining plant height are mentioned in (Table 5) revealed that Gibberellic acid concentrations significantly affected the plant height. Whereas the interaction between cultivars and Gibberellic acid concentrations showed non-significant results. The mean table presented that highest $(75.3 \mathrm{~cm})$ plant height was recorded in plants treated with gibberellic acid at the rate of $150 \mathrm{mgL}^{-1}$, followed by $(73.13 \mathrm{~cm})$ plant height treated with gibberellic acid concentration at the rate of $200 \mathrm{mgL}^{-1}$, while the least plant height $(53.59 \mathrm{~cm})$ was recorded in control treatment.

Plantheight increased with application ofGA $_{3}$ is due to the fact that it may promoted the cell elongation [22]. Similar results were recorded by [23]. Because of the gibberellic acid application the cell elongation and cell division in plants were enhanced, similarly also increased number of cell and cell length which might affect growth of gladiolus [24].

Table 5. Influence of gibberellic acid concentration and cultivars on the plant height (cm) of gladiolus

\begin{tabular}{|c|c|c|c|c|c|c|}
\hline \multirow{2}{*}{ Cultivars } & \multicolumn{5}{|c|}{ Gibberellic acid concentrations $\left(\mathrm{mgL}^{-1}\right)$} & \multirow[t]{2}{*}{ Mean } \\
\hline & $\mathbf{0}$ & 50 & 100 & 150 & 200 & \\
\hline White Prosperity & 50.92 & 75.83 & 69.42 & 80.00 & 75.25 & $\mathbf{7 0 . 2 8}$ \\
\hline Red Advance & 56.26 & 64.17 & 66.00 & 71.25 & 71.00 & 65.74 \\
\hline Mean & 53.59c & 70.00ab & 67.71b & $75.63 a$ & 73.13ab & \\
\hline
\end{tabular}

\section{Number of floret spike ${ }^{-1}$}

The data pertaining to number of floret spike $^{-1}$ of gladiolus as described in (Table 6) which showed that Gibberellic acid concentrations had significant effected the number of floret spike $^{-1}$ of gladiolus cultivars. While cultivars and their interaction showed non-significant results. The mean values demonstrated that more number (14.4) of floret spike ${ }^{-1}$ was observed in plants treated with200 $\mathrm{mgL}^{-1}$ gibberellic acid, followed by (14.1) with $150 \mathrm{mgL}^{-}$
${ }^{1}$ gibberellic acid treatment, while less number (10.4) of floret spike ${ }^{-1}$ were noted in plants in control treatment.

The increase in number of floret spike ${ }^{-1}$ was due to increase in no. of leaves and ultimately the leaf area which increase photosynthates needed to improve reproductive growth in plants [25]. More number of leaves can increase the amount of food required for number of floret spike ${ }^{-1}$. Thepresent results are in close conformity with [1]. 
Table 6. Influence of gibberellic acid concentration and cultivars on the number of floret spike $^{-1}$ of gladiolus

\begin{tabular}{|c|c|c|c|c|c|c|}
\hline \multirow{2}{*}{ Cultivars } & \multicolumn{5}{|c|}{ Gibberellic acid concentrations $\left(\mathrm{mgL}^{-1}\right)$} & \multirow[t]{2}{*}{ Mean } \\
\hline & $\mathbf{0}$ & $\mathbf{5 0}$ & 100 & 150 & 200 & \\
\hline White Prosperity & 10.5 & 11.8 & 14.0 & 14.2 & 14.1 & 12.9 \\
\hline Red Advance & 10.3 & 12.1 & 11.9 & 14.1 & 14.7 & 12.6 \\
\hline Mean & $14.4 \mathrm{c}$ & $11.9 \mathrm{~b}$ & 12.9ab & 14.1a & $14.4 a$ & \\
\hline
\end{tabular}

\section{Number of shoots plant ${ }^{-1}$}

Mean data for the number of shoots plant ${ }^{-1}$ is point out in (Table 7) showed that gibberellic acid and cultivars of gladiolus was significantly enhanced number of shoots per plant, whereas its interaction was found non-significant. The mean table value presented that more number of shoots were (2.7) noted in Red Advance cultivar while less number of shoots (2.1) plant $^{-1}$ were recorded in White Prosperity cultivar. The mean table value described that maximum number of shoots (3.2) plant $^{-1}$ was observed in $200 \mathrm{mgL}^{-1}$ Gibberellic acid concentration, followed by number of shoots (2.6) plant $^{-1}$ was noticed in plants with the application of $150 \mathrm{mgL}^{-1}$ Gibberellic acid concentration. The minimum number of shoot (1.8) plant $^{-1}$ were obtained in control treatment.

More number of shoots plant ${ }^{-1}$ were observed in Red Advance cultivar, which might be due to the more carbohydrates accumulation as a result of greater food producing units i.e. leaves. More food synthesized by leaves promoted the vegetative attributes that is number of shoots plant $^{-1}$ in Red Advance cultivar [12]. This study showed that number of shoot per plant was significantly increased with the application of Gibberellic acid in cultivar Red Advance. It may be due to the role of $\mathrm{GA}_{3}$ in various physiological process. [26] Reported that maximum shoots plant $^{-1}$ due to the application of soaking of corms with growth regulators in gladiolus. [27] Reported similar results and they found maximum shoots plant $^{-1}$ at $200 \mathrm{mgL}^{-}$ ${ }^{1}$ gibberellic acid. Increase in number of shoots plant $^{-1}$ might be the reason that growth regulators stimulate cell division and lateral bud development which result multiple shooting [28].

Table 7. Influence of gibberellic acid concentration and cultivars on the number of shoots plant $^{-1}$ of gladiolus

\begin{tabular}{|c|c|c|c|c|c|c|}
\hline \multirow{2}{*}{ Cultivars } & \multicolumn{5}{|c|}{ Gibberellic acid concentrations $\left(\mathrm{mgL}^{-1}\right)$} & \multirow[t]{2}{*}{ Mean } \\
\hline & $\mathbf{0}$ & 50 & 100 & 150 & 200 & \\
\hline White Prosperity & 1.4 & 1.8 & 2.1 & 2.4 & 2.9 & $2.1 \mathrm{~b}$ \\
\hline Red Advance & 2.2 & 2.5 & 2.6 & 2.7 & 3.4 & $2.7 \mathbf{a}$ \\
\hline Mean & $1.8 d$ & $2.1 \mathrm{c}$ & $2.4 \mathrm{bc}$ & $2.6 \mathrm{~b}$ & 3.2a & \\
\hline
\end{tabular}

\section{Length of spike plant ${ }^{-1}(\mathrm{~cm})$}

The data related to flower spike length $(\mathrm{cm})$ is presented in (Table 8) which described that Gibberellic acid concentrations had significant effected on the length of spike plant $^{-1}(\mathrm{~cm})$ of gladiolus. While the cultivars and theirinteraction showednon-significant results. The mean value of different
Gibberellic acid concentrations demonstrated that maximum $(57.15 \mathrm{~cm})$ length of spike plant ${ }^{-1}$ was gained by plants treated with150 $\mathrm{mgL}^{-1}$ Gibberellic acid concentration, followed by $(55.45 \mathrm{~cm})$ with the application of $200 \mathrm{mgL}^{-1}$ Gibberellic acid concentration, whereas minimum spike 
length plant ${ }^{-1}(45.73 \mathrm{~cm})$ was found in control treatment.

Gibberellic acid promotes vegetative growth and increases the photosynthetic and metabolic activities causing more transport and utilization of photosynthetic products
[12] in gladiolus due to which spike length and rachis length increased thereby allowing florets to grow larger [24]. These findings are supported by [29] in tuberose flower and [14] in gladiolus.

Table 8. Influence of gibberellic acid concentration and cultivars on the length of spike (cm) plant $^{-1}$ of gladiolus

\begin{tabular}{|c|c|c|c|c|c|c|}
\hline \multirow{2}{*}{ Cultivars } & \multicolumn{5}{|c|}{ Gibberellic acid concentrations $\left(\mathbf{m g L}^{-\mathbf{1}}\right)$} & \multirow{2}{*}{ Mean } \\
\cline { 2 - 7 } & $\mathbf{0}$ & $\mathbf{5 0}$ & $\mathbf{1 0 0}$ & $\mathbf{1 5 0}$ & $\mathbf{2 0 0}$ & \\
\hline White Prosperity & 45.80 & 45.90 & 49.09 & 55.67 & 55.25 & $\mathbf{5 0 . 3 4}$ \\
\hline Red Advance & 45.67 & 53.29 & 54.12 & 58.63 & 55.67 & $\mathbf{5 3 . 4 7}$ \\
\hline Mean & $\mathbf{4 5 . 7 3 d}$ & $\mathbf{4 9 . 5 9 c d}$ & $\mathbf{5 1 . 5 9 b c}$ & $\mathbf{5 7 . 1 5 a}$ & $\mathbf{5 5 . 4 6 a b}$ & \\
\hline
\end{tabular}

\section{Days to flower opening}

Data pertaining days to flower opening is mentioned in (Table 9) show that cultivars and gibberellic level are highly significantly effected days to flowering emergence and their interaction are non-significant. The mean table data showed that less number of days (74.5) to flower opening were noted in Red Advance cultivar, while more number of days (76.1) were obtained by White Prosperity. Different concentrations of Gibberellic acid had significant response for days to floret opening. Less number of days (72.7) to flower opening were found in 200 $\mathrm{mgL}^{-1}$ gibberellic acid $\left(\mathrm{GA}_{3}\right)$, followed by (73.9) days to floret opening observed in plant treated with $150 \mathrm{mgL}^{-1}$ Gibberellic acid, while the more number of days (79.2) to floret opening was resulted from plant in control treatment.

Early flower opening in Red Advance cultivar might be due to the early vegetative growth. As more photosynthates production was found in the plants of Red Advance which enhance the vegetative growth parameters and resulted in the earlier completion of life cycle, hence promoted the reproductive growth as well $[12,19,30]$. Different concentrations of $\mathrm{GA}_{3}$ and cultivars significantly influenced on days to flowering of gladiolus (Table 9). This is might be regulating effect of increased vegetative growth in early phase due to increased photosynthesis and $\mathrm{Co}_{2}$ fixation. Further exogenous application of $\mathrm{GA}_{3}$ influences early floral initiation. It was also reported by $[14,31-33]$ that gibberellic acid promoted vegetative growth and increased the photosynthetic and metabolic activities caused more transport and utilization of photosynthetic products resulted early flowering in gladiolus.

Table 9. Influence of gibberellic acid concentration and cultivars on the days to flower opening of gladiolus

\begin{tabular}{|c|c|c|c|c|c|c|}
\hline \multirow{2}{*}{ Cultivars } & \multicolumn{5}{|c|}{ Gibberellic acid concentrations $\left(\mathrm{mgL}^{-1}\right)$} & \multirow[t]{2}{*}{ Mean } \\
\hline & $\mathbf{0}$ & 50 & 100 & 150 & 200 & \\
\hline White Prosperity & 80.0 & 77.3 & 76.4 & 75.5 & 74.1 & $76.1 a$ \\
\hline Red Advance & 78.5 & 75.8 & 74.4 & 72.4 & 71.4 & $74.5 \mathrm{~b}$ \\
\hline Mean & $79.2 \mathrm{a}$ & $76.6 b$ & $75.4 \mathrm{c}$ & 73.9d & $72.7 e$ & \\
\hline
\end{tabular}




\section{Number of daughter corms plant ${ }^{-1}$}

Data related to Number of daughter corms plant $^{-1}$ is given in (Table 10) which showed that cultivars and Gibberellic acid were significant, while their interaction showed non-significant results. Gladiolus cultivars significantly affected number of daughter corms produced plant $^{-1}$ and their mean values shows that maximum number of daughter corms (3.0) plant $^{-1}$ were gained by Red Advance, while minimum number of daughter corms (2.7) plant $^{-1}$ was noticed in White Prosperity cultivar. A significant response was observed regarding gibberellic acid for number of daughter corms plant $^{-1}$ of gladiolus. More number of daughter corms (3.5) plant $^{-1}$ were obtained in plants with the application of $200 \mathrm{mgL}^{-1}$ Gibberellic acid concentration, followed by (3.3)number of daughter corms plant $^{-1}$ treated with 150 $\mathrm{mgL}^{-1}$ Gibberellic acid concentration and less number (2.4) of daughter corms produced plant $^{-1}$ were recorded in control treatment.

Higher number of corms plant ${ }^{-1}$ in Red Advance cultivar, it might be due to the more accumulation of photosynthates production and favorable climatic conditions [34]. It was found that before plantation corms soaking for 24 hours increased number of daughter and cormelsplant ${ }^{-1}$ as compared to 12 hour soaking [35]. These findings are supported by [36] who found that increase concentrations of $\mathrm{GA}_{3}$ increased the corms number.

Table 10. Influence of gibberellic acid concentration and cultivars on the number of daughter corms plant ${ }^{-1}$ of gladiolus

\begin{tabular}{|c|c|c|c|c|c|c|}
\hline \multirow{2}{*}{ Cultivars } & \multicolumn{5}{|c|}{ Gibberellic acid concentrations $\left(\mathrm{mgL}^{-1}\right)$} & \multirow[t]{2}{*}{ Mean } \\
\hline & $\mathbf{0}$ & 50 & 100 & 150 & 200 & \\
\hline White Prosperity & 2.2 & 2.4 & 2.5 & 3.2 & 3.4 & $2.7 \mathrm{~b}$ \\
\hline Red Advance & 2.6 & 2.5 & 3.1 & 3.4 & 3.6 & 3.0a \\
\hline Mean & $2.4 \mathrm{c}$ & $2.5 \mathrm{bc}$ & $2.8 b$ & 3.3a & 3.5a & \\
\hline
\end{tabular}

\section{Diameter of corms (cm)}

The observation about diameter of corms $(\mathrm{cm})$ is tabulated in (Table 11) which described that cultivars and different gibberellic acid levels significantly affected corms diameter, where their interaction were not showed significant effect. The mean value identify that maximum corm diameter was observed $(3.04 \mathrm{~cm})$ in Red Advance and minimum corm diameter was noticed (2.87 $\mathrm{cm}$ ) in White Prosperity. The mean value of different Gibberellic acid concentrations revealed that maximum corm diameter $(3.37$ $\mathrm{cm})$ was obtained by plants treated with 150 $\mathrm{mgL}^{-1}$ Gibberellic acid concentration, followed by (3.25) with $200 \mathrm{mgL}^{-}$ ${ }^{1}$ Gibberellic acid concentration while the lowest diameter of corm (2.47) were gained by plants in control treatment.

There are different factors, which can enhance the diameter of corms. It might be due to the genetic makeup of cultivar or may be the favorable environmental conditions. Maximum corm diameter was observed in Red Advance cultivar, might be due to the application of gibberellic acid due to which the plants produced more photosynthates and carbohydrates accumulation, as a result cause large corm size. Gibberellins lead to increased cell division and cell growth apparently which lead to increased elongation of root [37] and it enhances corm diameter. 
Table 11. Influence of gibberellic acid concentration and cultivars on the corms diameter (cm) of gladiolus

\begin{tabular}{|c|c|c|c|c|c|c|}
\hline \multirow{2}{*}{ Cultivars } & \multicolumn{5}{|c|}{ Gibberellic acid concentrations $\left(\mathrm{mgL}^{-1}\right)$} & \multirow[t]{2}{*}{ Mean } \\
\hline & $\mathbf{0}$ & $\mathbf{5 0}$ & 100 & 150 & 200 & \\
\hline White Prosperity & 2.35 & 2.79 & 2.82 & 3.27 & 3.13 & $2.87 b$ \\
\hline Red Advance & 2.59 & 2.89 & 2.89 & 3.46 & 3.38 & 3.04a \\
\hline Mean & $2.47 \mathrm{c}$ & $2.84 b$ & $2.85 b$ & 3.37a & $3.25 a$ & \\
\hline
\end{tabular}

\section{Corms weight (g)}

In (Table 12) demonstrated the mean values of corm weight which clarified that cultivarsof gladiolus and different concentrations of Gibberellic acid significantly affected corm weight but their interaction showed non-significant results. Mean data Table illustrated that maximum corm weight (13.39 g) was observed in Red Advance cultivar, while the lowest corm weight $(12.03 \mathrm{~g})$ was obtained by White Prosperity. Maximum corm weight (14.90 g) were produced by the plants with the application of Gibberellic acid at the concentration of $150 \mathrm{mgL}^{-1}$, followed by $(14.53 \mathrm{~g})$ treated with $200 \mathrm{mgL}^{-1}$ Gibberellic acid concentration and the minimum corms weight $(10.71 \mathrm{~g})$ were observed in control treatment.
Maximum corm weight were obtained in Red Advance cultivar, it might be due to the best adaptation of gladiolus cultivar and more accumulation of photosynthates and carbohydrates production in which it had obtained a good and well developed plants, as a result it promoted the best corm weight [38]. More food is reserved by larger size corms which help in growth and development, with the combination of 150 $\mathrm{mgL}^{-1}$ gibberellic acid $\left(\mathrm{GA}_{3}\right)$ increases the single corm weight about 59\% compared to treated plants with $100 \mathrm{mgL}^{-1}$ gibberellic acid $\left(\mathrm{GA}_{3}\right)$, which was also reported by $[14$, 39, 40]. These results are strongly in conformity with the findings of [19] who also reported that the increased in corm weight with $150 \mathrm{mgL}^{-1}$ gibberellic acid treatment.

Table 12. Influence of gibberellic acid concentration and cultivars on the corms weight ( $\mathrm{g}$ ) of gladiolus

\begin{tabular}{|c|c|c|c|c|c|c|}
\hline \multirow{2}{*}{ Cultivars } & \multicolumn{5}{|c|}{ Gibberellic acid concentrations $\left(\mathrm{mgL}^{-1}\right)$} & \multirow[t]{2}{*}{ Mean } \\
\hline & $\mathbf{0}$ & 50 & 100 & 150 & 200 & \\
\hline White Prosperity & 10.25 & 10.60 & 10.70 & 14.41 & 14.20 & $12.03 b$ \\
\hline Red Advance & 11.17 & 12.43 & 13.10 & 15.38 & 14.87 & 13.39a \\
\hline Mean & 10.71c & $11.52 b$ & $11.90 b$ & $14.90 a$ & 14.53a & \\
\hline
\end{tabular}

\section{Survival percentage}

The mean data for survival percentage is showed in (Table 13) which showed that cultivars, Gibberellic acid concentrations and their interaction had a significant effect on survival percentage of gladiolus. There was significant variation in survival percentage among the gladiolus cultivars. The mean data showed that maximum survival percentage (70.9) was recorded in
Red Advance cultivar, while the less survival percentage (62.7) was noticed in White Prosperity cultivar. The Gibberellic acid had significant effect on survival percentage of gladiolus cultivars. However the maximum survival percentage (88.5) was recorded in plants applied with 200 $\mathrm{mgL}^{-1}$ gibberellic acid concentration, followed by (80.1) treated with $150 \mathrm{mgL}^{-}$ ${ }^{1}$ gibberellic acid, while less survival \% 
(42.5) were observed in control treatment. The interaction was found significant between gladiolus cultivars and gibberellic acid concentrations on survival percentage. However, more survival \% (89.5) was observed in Red Advance cultivar treated with $200 \mathrm{mgL}^{-1}$ gibberellic acid while, less survival \% (39.3) was observed in White Prosperity cultivar in control treatment.

From the results it was found that, more survival percentage was noted in plants of Red Advance cultivar that were treated with $200 \mathrm{mgL}^{-1}$ gibberellic acid $\left(\mathrm{GA}_{3}\right)$. It might be due to the genetic makeup or favorable environmental conditions that were available for the plants of Red Advance cultivar [19]. Moreover, the presence of high of photosynthates resulted in the enhancement of vegetative and reproductive growth of plants, hence it can be the reason of high rate of survival percentage [12]. $\mathrm{GA}_{3}$ application can also trigger the rapid cell division, cell elongation and nutrient availability, which leads to the more survival percentage of plants [41].

Table 13. Influence of gibberellic acid concentration and cultivars on the survival percentage of gladiolus

\begin{tabular}{|c|c|c|c|c|c|c|}
\hline \multirow{2}{*}{ Cultivars } & \multicolumn{5}{|c|}{ Gibberellic acid concentrations $\left(\mathrm{mgL}^{-1}\right)$} & \multirow[t]{2}{*}{ Mean } \\
\hline & 0 & 50 & 100 & 150 & 200 & \\
\hline White Prosperity & 39.3 & 50.0 & 61.7 & 75.0 & 87.5 & $62.7 b$ \\
\hline Red Advance & 45.7 & 61.2 & 73.0 & 85.2 & 89.5 & 70.9a \\
\hline Mean & 42.5e & 55.6d & $67.3 \mathrm{c}$ & 80.1b & 88.5a & \\
\hline
\end{tabular}

\section{Conclusion}

It is concluded from the above results that Gibberellic acid concentrations and cultivars significantly influenced vegetative, floral and corm yield of Gladiolus. Gladioulus cultivar Red Advance had significantly higher number of leaves plant ${ }^{-1}$, number of shoots plant $^{-1}$, number of daughters corm plant $^{-1}$, length of spike plant ${ }^{-1}$, corms diameter, corm weight, survival percentage, days to spike emergence and days to floret opening. Gibberellic acid concentration at the rate of $200 \mathrm{mgL}^{-1}$ showed significant effect on sprouting percentage, number of leaves plant $^{-1}$, number of shoots plant ${ }^{-1}$, number of daughter's corm plant ${ }^{-1}$, survival percentage, number of days to corm sprouting, days to spike emergence and days to floret opening. Gibberellic acid at 150 $\mathrm{mgL}^{-1}$ exhibited significant effect on plant height $(\mathrm{cm})$, length of spike plan ${ }^{\mathrm{t}-1}$, corms diameter and corm weight.

\section{Authors' contributions}

Conceived and designed the experiments: A Rahman, G Nabi \& W Khan, Performed the experiments: A Rahman, W Khan, M Ilyas \& B Ali, Analyzed the data: M N Khan, M Hissam, M Ilyas \& Y Ali, Contributed materials/ analysis tools: A Rahman, G Nabi $\&$ M N Khan, Wrote the paper: M Ilyas

\section{References}

1. Negi SS, Sharma TVRS, Raghava SPS \& Shrinivasan VR (1982). Variability studies in gladiolus. Indian J Hort (39): 269-272.

2. Hutchinson J (1959). Families of flowering plants. Macmillan and Co Ltd, St Martins St, London pp 792.

3. Halder NK, Siddiqui MA, Ahmad R, Sharifuzzaman SM \& Begum KA (2007). Effect of boron and zinc fertilization on flower yield and quality of gladiolus in grey terrace soils of Bangladesh. J Soil Nature 1(3): 40-45.

4. Singh AP \& Dohare SR (1994). Maximization of corm and cormel production in gladiolus. In: J. Prakash and 
K. R. Bhandary (Eds.). FloricultureTechnology, trades and trends. Oxford \& IBH Pub Co Pvt Ltd, India 205-208.

5. Uddin FM, Rahman MM, Rabbani MG \& Mannan MA (2002). Effect of corm size and depth of planting on the growth and flowering of gladiolus. Pak J Biol Sci 5(5): 553-555.

6. Vijai KU, Singh RP \& Singh AR (2007). Effect of gibberellic acid and growing media on vegetative and floral attributes of gladiolus. Indian J Hort (64): 73-76.

7. Farid UM, Rahman MM, Rabbani MG \& Mannam MA (2002). Effect of corm size and depth of planting on the growth and floweringof gladiolus. Pak J Biol Sci 5(5): 553-555.

8. Steel RGDD \& Torrie JH (1980). Principles and procedures of statistics. A biometrical approach, $2^{\text {nd }}$ Edition.

9. Gowda JVN (1985). Effect of gibberellic acid on growth and flowering of rose cv. Super Star. Indian Rose Ann IV: 185-187.

10. Nagarajaiah C \& Reddy TV (1986). Quality of Queen Elizabeth cut roses as influenced by $\mathrm{GA}_{3}$. Mysore J of Agri Sci 20(4): 292-295.

11. Padmalatha T, Reddy GS, Chandrasekhar R, Shankar AS \& Chaturvedi A (2013). Effect of pre-planting soaking of corms with chemicals and plant growth regulators on dormancy breaking and corm and cormel production in Gladiolus. IJPAES 3(1): 28-33.

12. Al-Humaid AI (2004). Adaptation of some gladiolus cultivars to Al-Qassim environmental conditions. Arab gulf $J$ Scient Res (22): 248-256.

13. Quyoom S (2011). Role of growth regulators in gladiolus cv. American Beauty. Indian J Hort 1(1): 53-54.

14. Sudhakar M \& Kumar SR (2012). Effect of growth regulators on growth, flowering and corm production of gladiolus (Gladiolus grandiflorus L.) cv. White Friendship. Indian J Plant Sci 1(2-3): 133-136.

15. Hooley R (1994). Gibberellins: perception, transduction and responses. Plant Mol Biol 26(5): 15291555.

16. Saute M, Seagull RS \& Kende H (1993). Internodal elongation and orientation of cellulose micro fibrils and microtubules in deep-water rice. Planta 190(3): 354362.

17. Ross JJ, Reid JB, Gaskin P \& MacMillan J (1989). Internode length in Pisum. Estimation of GA1 levels in genotypes Le, le and led. Physiologiaplantarum 76(2): $\quad$ 173176.

18. Xu YL, Gage DA \& Zeevaart JA (1997). Gibberellins and Stem Growth in Arabidopsis thaliana (Effects of Photoperiod on Expression of the $\mathrm{GA}_{3}$ and $\mathrm{GA}_{5}$ Loci). Plant Physiol 114(4): 1471-1476.

19. Zubair M, Wazir FK, Akhtar S \& Ayub G (2006). Planting dates affect floral characteristics of gladiolus under the soil and climatic conditions of Peshawar. Pak J Biol Sci 9(9): 1669-1676.

20. Mittal SP (1967). Studies on the effect of gibberellin on growth and flowering of dahlia. Madras Agri J 54: 103-107.

21. Kumari S, Patel BS \& Mahawer LN (2011). Influence of gibberellic acid and planting date on growth and flowering in gladiolus cv. Yellow Frilled. $J$ of Hort Sci.

22. Tonecki J (1980). Effect of growth regulators on shoot apex differentiation and change in sugars and free amino acids in gladiolus. Acta Hort 107: 347-355.

23. Aier S, Langthasa S, Hazarika DN, Gautam BP \& Goswami RK (2015). Influence of GA and $\mathrm{BA}$ on Morphological, Phenological and yield attributes in gladiolus cv. Red Candyman. IOSR J Agri Veter Sci (8): 3742.

24. Taiz L \& Zeiger E (1998). Plant Phsiology (Sinauer Associate Inc. Publishers) 2nd Ed pp 792.

25. Yousif S, Mahmoud S \& Safar A (2006). Effect of $\mathrm{GA}_{3}$ Treatment and Nitrogen on 
Growth and Development of Gladiolus Corms. Pak J of Biol Sci 9(13): 25162519.

26. Baskaran V \& Misra RL (2007). Effect of plant growth regulators on growth and flowering of gladiolus. Indian $J$ Hort 64(4): 479-482.

27. Chopde N, Patil A \& Bhande MH (2015). Growth, yield and quality of gladiolus as influenced by growth regulators and methods of application. Plant Archives 15(2): 691-694.

28. Murti GSR \& Upreti KK (1995). Use of Growth Regulators in Ornamental Plants, Advances in Horticulture. Ornamental plants, (Malhotra Publishing House, New Delhi, India).Vol 12-863-883.

29. Singh B \& Srivastava R (2009). Effect of foliar application of growth regulators on flowering of tuberose (Polianthes tuberosa L.). J of Orna Hort 12(3): 188192.

30. Javvad ND, Mahmood PY, Roya K \& Hamideh JH (2012). Effect of cultivar on water relations and postharvest quality of gerbera (Gerbera jamesonii Bolus ex. Hook f.) cutflower. World Appl Sci J (18): 698-703.

31. Devadanam APB, Sable BN, Shinde \& Haldewad AM (2007). Effect of foliar spray of plant growth regulators on growth and yield of tuberose (Polianthes tuberose L.). J Mah Agril Univ (32): 282-283.

32. Dogra S, Pandey RK \& Bhat DJ (2012). Influence of gibberellic acid and plant geometry on growth, flowering and corm production in gladiolus (Gladiolus grandiflorus) under Jammu agroclimate. Int J Pharm Bio Sci 3(4): 1083-1090.

33. Sharma JR, Gupta RB \& Panwar RD (2004). Growth flowering and corm production gladiolus cv. Friendship as influenced by foliar application of nutrients and growth regulators. J Orna Hort 7(3-4): 154-158.

34. Khan MA \& Ahmad I (2004). Growth and flowering of (Gladiolus hortulanus L.) cv. Winf Song as influences by various levels of NPK. Intl J Agri Biol (6): 1037-1039.

35. Pal \& Chowdhury $T$ (1998). Effect of growth regulators and duration of soaking on sprouting, growth, flowering and corm yield of gladiolus cv. Tropic Sea. Hort J 11(2): 69-77.

36. Rajaram D, Mukherjee \& Manuja S (2002). Plant growth regulators affect the development of both corms and cormels in Gladiolus. Hort Sci 37(2): 343-344.

37. Stewart DA \& Jones RI (1977). The role of extensibility and turgor in gibberellins and dark stimulated growth. Plant Physiol (59): 61-68.

38. Suh JK \& Kwack BH (1990). The corm formation of gladiolus influenced by dormancy breaking methods, cormel planting and corm harvesting times. J Kor Soc Hort Sci 31(3): 294-299.

39. Amin NU, Khattak AM, Ahmad I, Ara N, Alam A, Ali A \& Ali I (2013). Corm and cormel size of gladiolus greatly influenced growth and development of subsequent corm production. Pak J Bot 45(4): 1407-1409.

40. Bhat ZA, Paul TM \& Mir MM (2009). Effect of corm size and planting geometry on growth, flowering and corm production in gladiolus $\mathrm{cv}$. white prosperity. J Orna Hort 12(1): 35-38.

41. Saleem M, Ahmad I \& Khan MA (2013). Cultivar Effects on Growth, Yield and Cormel Production of Gladiolus (Gladiolus grandiflorus L.). J Ornam and Hort Plants 3(1): 39-48. 